\title{
CZYNNIKI KSZTAŁTUJĄCE OBRAZ CIAŁA U OSÓB Z WYBRANYMI CHOROBAMI DERMATOLOGICZNYMI*
}

\section{FACTORS INFLUENCING BODY IMAGE IN INDIVIDUALS WITH SELECTED DERMATOLOGICAL DISEASES}

\author{
Zakład Nauk Humanistycznych w Medycynie Pomorskiego Uniwersytetu Medycznego w Szczecinie \\ ul. Żołnierska 48, 71-210 Szczecin \\ Kierownik: dr n. hum. Tadeusz Dyk
}

\begin{abstract}
Summary
Introduction: The aim of this work was to examine the relationship between body concept and personality, and sociodemographic, physical and medical factors in dermatological patients with skin lesions localized in socially visible body areas.

Material and methods: The study was carried out in 160 dermatological patients ( 80 females and 80 males) aged $30-60$ years $($ mean $=48.26 ; \mathrm{SD}=9.15)$ whose skin lesions were localized in the area of the face/head and/or hands. Body image was measured with the Body Image Questionnaire based on the Body Cathexis Scale of P.F. Secord and S.J. Jourard. The self concept was measured with the Adjective Check List of H.G. Gough and A.B. Heilbrun, and The Wheel Questionnaire of Ben Shalit.

Conclusions: Body self image of dermatological patients was influenced mostly by personality traits.
\end{abstract}

K e y w o r d s: body image - personality - quantitative research - dermatology.

\section{Streszczenie}

Wstęp: Celem pracy było zbadanie związku między obrazem ciała a czynnikami osobowościowymi, socjodemograficznymi, fizycznymi i medycznymi u osób chorych dermatologicznie, u których zmiany chorobowe zlokalizowane są w widocznych społecznie obszarach ciała.

Materiat i metody: Badaniami objęto 160 osób chorych dermatologicznie ( 80 kobiet i 80 mężczyzn) w wieku 30-65 lat (średnia $=48,26 ; \mathrm{SD}=9,15)$, u których zmiany skórne zlokalizowane były w obszarze twarzy/głowy i/lub dłoni. Do pomiaru obrazu ciała wykorzystano Kwestionariusz Obrazu Ciała będący parafrazą Body Cathexis Scale autorstwa Secorda i Jourarda. Obraz siebie zmierzono za pomocą Testu Przymiotnikowego ACL Gougha i Heilbruna oraz Kwestionariusza Stylu Spostrzegania „Koło” Bena Shalita.

Wnioski: Obraz ciała osób chorych dermatologicznie kształtowany był przede wszystkim przez właściwości osobowości.

H a s ł a: obraz ciała - osobowość - badania jakościowe dermatologia.

\section{Wstęp}

Doznania cielesne stanowią podstawę budowania osobowości, ,ja” psychicznego, jako czegoś odrębnego od otaczającego środowiska [1]. Ważnym czynnikiem wpływającym na sposób, w jaki dana osoba postrzega siebie, w tym na jej stosunek do własnego ciała, ma przekaz społeczny. Przekaz ten może być realizowany pośrednio - poprzez

* Na podstawie rozprawy doktorskiej przyjętej przez Radę Wydziału Nauk Społecznych Katolickiego Uniwersytetu Lubelskiego Jana Pawła II. Promotor: dr hab. Jan Tylka. Oryginalny maszynopis obejmuje: 287 stron, 63 tabele, 41 rycin, 179 pozycji piśmiennictwa. 
internalizację standardów rodzinnych i kulturowych, obserwacje dotyczące innych osób, ekspozycję określonych modeli w mediach, jak również bezpośrednio - w formie ogólnikowych komentarzy, konkretnych pytań dotyczących wyglądu, otwartego wyśmiewania poszczególnych cech fizycznych, a także różnorodnych sygnałów niewerbalnych $[2,3,4,5,6]$. Prawdopodobieństwo ukształtowania się negatywnego stosunku do własnej osoby zwiększa się, gdy jednostka często doświadcza krytycznych reakcji ze strony bliższego i dalszego otoczenia społecznego [1, 6]. Czynniki społeczne mogą mieć niekorzystny wpływ na proces formowania ,ja" cielesnego i psychicznego, szczególnie w przypadku osoby chorej, która dodatkowo doświadcza negatywnych bodźców pochodzących z jej własnego ciała [7]. Gdy choroba staje się widoczna, a zwłaszcza gdy jej rezultatem jest zniekształcenie ciała, które może być z łatwością zauważone przez innych, wówczas osoba chora staje się szczególnie podatna na negatywne reakcje społeczne $[8,9,10]$. Tym samym zwiększa się prawdopodobieństwo odrzucenia przez nią tych cielesnych aspektów siebie, które są zdeformowane lub utrzymywania się negatywnego obrazu własnego ciała $[2,7]$.

Zagadnienie obrazu ciała jest ściśle związane $\mathrm{z}$ chorobą przewlekłą z kilku powodów: 1) niezadowoleniu z ciała towarzyszy niska samoocena oraz większe prawdopodobieństwo lęku i depresji; 2) ocena ciała może wpływać na stopień stosowania się chorego do planu leczenia oraz gotowość do przyjęcia aktywnej roli w procesie leczenia; 3 ) negatywne ustosunkowanie do własnego ciała może być zmienione poprzez oddziaływania psychologiczne i edukacyjne [11].

Schorzenia skóry relatywnie rzadko stanowią poważne zagrożenie dla zdrowia czy życia pacjenta i przeważnie nie prowadzą do upośledzenia jego funkcjonalności, co może skłaniać osoby z otoczenia chorego, $\mathrm{w}$ tym również personel medyczny, do bagatelizowania medycznych i psychospołecznych trudności będących jego udziałem [12]. Szczególnym obciążeniem dla osób zmagających się z chorobami dermatologicznymi jest niemożność ukrycia zmian skórnych, zwłaszcza gdy są one zlokalizowane w ,widocznych społecznie" obszarach ciała, takich jak twarz lub dłonie $[12,13]$. Towarzyszy temu doświadczanie stygmatyzacji, co często staje się przyczyną negatywnych emocji (jak np. gniew, lęk, zakłopotanie) w istotny sposób obniżających jakość życia tych chorych [12, 14, 15].

Choroby skóry zaburzają nie tylko somatyczny wymiar funkcjonowania człowieka, ale także, a może przede wszystkim, zmieniają jakość jego funkcjonowania w wymiarze psychicznym i społecznym. Dlatego postuluje się konieczność włączenia opieki psychologicznej w proces terapii tych osób [16].

Ważnym elementem procesu adaptacji do choroby dermatologicznej jest akceptacja odmienności własnego wyglądu od szeroko rozumianej normy oraz fluktuacyjności obrazu ciała związanej z periodycznością występowania zmian chorobowych [12]. Badanie różnych aspektów obrazu ciała osób cierpiących na choroby skóry jest niezbędne w celu udzielenia im odpowiedniej pomocy psychologicznej i podjęcia działań zmierzających do podniesienia poziomu ich akceptacji siebie.

Różne czynniki pozamedyczne mogą kształtować sposób odnoszenia się do własnego ciała. Najczęściej wymienia się cechy fizyczne - np. wygląd twarzy [17, 18] czy właściwości sylwetki, takie jak masa ciała (BMI) [19, 20], ale także czynniki socjodemograficzne - płeć, wiek, wykształcenie, stan cywilny [21, 22, 23, 24, 25, 26].

Wyniki wielu badań przeprowadzonych zarówno na populacjach osób zdrowych, jak i chorych wskazują, że sposób postrzegania własnego ciała jest związany z posiadanymi cechami osobowości [19, 22, 27, 28].

Celem pracy była psychologiczna analiza związków między obrazem ciała a czynnikami osobowościowymi, socjodemograficznymi, fizycznymi i medycznymi u osób z wybranymi chorobami dermatologicznymi, u których zmiany chorobowe zlokalizowane są $\mathrm{w}$ widocznych społecznie obszarach ciała.

\section{Material i metody}

Podstawą teoretyczną analizy obrazu ciała była koncepcja Franzoi [29], której podstawowym założeniem jest to, że ciało można ujmować $\mathrm{z}$ dwóch punktów widzenia:

1) wyglądu fizycznego, czyli tego, jak ciało prezentuje się innym - wówczas dana osoba próbuje przyjąć punkt widzenia obserwatora swojego ciała i ocenia je przede wszystkim pod względem atrakcyjności fizycznej;

2) sposobu funkcjonowania, czyli tego, jak ciało działa wówczas dana osoba koncentruje się na sposobie doznawania własnego ciała i ocenia je pod względem sprawności.

W pracy przyjęto założenie, że choroba, która zasadniczo zamienia ciało pod względem danego aspektu jego ujmowania (wyglądu vs funkcjonowania) może mieć istotne znaczenie dla sposobu oceny tego aspektu ciała. W analizie obrazu ciała uwzględniono także czas choroby.

\section{Charakterystyka badanej grupy}

Do badań włączono 160 pacjentów chorych dermatologicznie w wieku 30-65 lat (średnia $=48,26 ; \mathrm{SD}=9,15$ ), u których zmiany skórne w momencie badania zlokalizowane były w obszarze twarzy/głowy i/lub dłoni, przy czym zadbano o równą liczebność kobiet i mężczyzn. Spośród badanych 74 osoby cierpiały na łuszczycę, u 34 zdiagnozowano choroby alergiczne skóry, 23 miały choroby kolagenowe tkanki łącznej, 9 chorowało na trądzik różowaty, a u pozostałych 20 zdiagnozowano inne choroby skóry (np. łysienie plackowate, liszaj płaski).

\section{Zastosowane narzędzia pomiarowe}

Zastosowano dwa rodzaje narzędzi pozwalających na określenie obrazu siebie osób badanych, przy czym jedno z nich miało charakter otwarty (i tym samym pozwalało osobie badanej na bardziej dowolny sposób wyrażenia swojej oceny), a drugie formę zamkniętą, w której osoba badana 
może jedynie wybrać jedną z przedstawionych do wyboru opcji. Były to Kwestionariusz Stylu Spostrzegania „Koło” Bena Shalita oraz Test Przymiotników ACL w opracowaniu Zenomeny Płużek. Do pomiaru obrazu ciała zastosowano Kwestionariusz Obrazu Ciała (KOC) będący parafrazą Body Cathexis Scale autorstwa Secorda i Jourarda.

\section{Procedura badania}

Kwestionariusz Stylu Spostrzegania „Koło” Bena Shalita może być wykorzystywany do badania spostrzegania różnych aspektów rzeczywistości, w tym także własnej osoby i umożliwia dokonanie charakterystyki zarówno struktury, jak i treści obrazu siebie. Zadaniem osoby badanej jest wypisanie w specjalnym diagramie w formie koła charakterystycznych dla siebie właściwości (tzw. czynników), przy czym najczęściej stosuje się wersję diagramu zawierającą 12 segmentów. Następnie osoba badana przypisuje im rangi, szeregując cechy od najbardziej (ranga 1) do najmniej (ranga 12) istotnej dla siebie. Na koniec prosi się ją o ocenę każdego czynnika na wymiarze wartościującym: czy i w jakim stopniu jest on pozytywny bądź negatywny. Każdej z podanych cech/właściwości przypisuje się jedną z pięciu ocen, które oznacza się symbolami +, - lub cyfrą 0 , przy czym dwa plusy to ocena bardzo pozytywna, jeden plus - pozytywna, zero - ani pozytywna, ani negatywna, jeden minus - negatywna i dwa minusy - bardzo negatywna [30].

Sposób obliczania wskaźników opisujących strukturę i treść obrazu siebie został szczegółowo opisany w innym artykule [31]. Na potrzeby tej pracy wykorzystano jedynie wskaźniki dotyczące treści obrazu własnej osoby. Były to następujące kategorie: Cielesność, Funkcjonowanie poznawczo-intelektualne, Relacje interpersonalne, Sfera emocjonalno-afektywna, Właściwości osobowości, Inna [31].

Test Przymiotników ACL autorstwa Gougha i Heilbruna w opracowaniu Płużek jest powszechnie znanym i często stosowanym samoopisowym testem osobowości, którego ogólnym założeniem jest to, że osoby wybierające różne cechy do opisu siebie rzeczywiście różnią się między sobą w zakresie funkcjonowania psychospołecznego. Test początkowo tworzył 24 skale nawiązujące do różnych koncepcji teoretycznych, natomiast aktualna jego wersja, którą wykorzystano w niniejszej pracy, powstała w $1980 \mathrm{r}$. i zawiera 37 skal. Oprócz modyfikacji związanych z dodaniem kilkunastu nowych skal oraz odmiennym ich uporządkowaniu, wprowadzono zmiany w kluczach oraz sposobie przeliczania wyników surowych na standaryzowane [32]. Obecnie Test Przymiotników ACL-37 zawiera 300 uporządkowanych losowo przymiotników odnoszących się do różnych aspektów osobowości. Narzędzie to może być stosowane do pomiaru realnego obrazu siebie (wersja „Jaki jesteś") i wówczas zadaniem osoby badanej jest wybranie tych określeń, które jej zdaniem najlepiej ją opisują oraz idealnego obrazu siebie (,Jaki chciałbyś być”), gdy prosi się osobę badaną o wskazanie cech, z jakimi chciałaby się identyfikować. Na potrzeby niniejszej pracy wykorzystano ACL jako wskaźnik realnego obrazu siebie, który składa się z 5 części:

1) modus operandi - 4 skale i przeznaczona jest do formalnej oceny profilu danej osoby (ilość wybranych przymiotników, ich typowość, pozytywność i negatywność);

2) skale potrzeb - 15 skal określających korelaty potrzeb zbudowanych w nawiązaniu do teorii Murraya (są to następujące potrzeby: osiągnięć, dominacji, wytrwałości, porządku, rozumienia siebie i innych, opiekowania się, afiliacji, kontaktów heteroseksualnych, ujawniania się, autonomii, agresji, zmiany, wsparcia ze strony innych, poniżania się, podporządkowania);

3) skale tematyczne - 9 skal opisujących różne aspekty lub składowe zachowań interpersonalnych (są to: gotowość na pomoc i poradę innych ludzi, samokontrola, zaufanie do siebie, przystosowanie osobiste, skala idealnego obrazu siebie, skala osobowości twórczej, skala uzdolnień przywódczych, skala męskości, skala kobiecości);

4) skale analizy transakcyjnej - 5 skal opisujących różne stany ego, skonstruowanych w oparciu o koncepcję Berne'a (są to: Krytyczny Rodzic, Wychowawczy Rodzic, Dorosły, Wolne Dziecko, Przystosowane Dziecko);

5) skale oryginalności - inteligencji - 4 skale opisujące twórczość i inteligencję wg koncepcji Welsha (są to: Wysoka oryginalność - niska inteligencja, Wysoka oryginalność wysoka inteligencja, Niska oryginalność - niska inteligencja, Niska oryginalność - wysoka inteligencja).

Kwestionariusz Obrazu Ciała stanowi parafrazę Body Cathexis Scale autorstwa Secorda i Jourarda, którą to skalę autorzy opracowali w 1953 r. Oryginalny test składa się z dwóch części - skali dotyczącej ustosunkowania się do własnego ciała Body-Cathexis Scale (BCS) oraz skali dotyczącej różnych aspektów osobowości Self-Cathexis Scale (SCS) [33].

Na potrzeby niniejszej pracy dokonano następujących modyfikacji:

- dodano elementy ciała dotyczące obszaru twarzy, tj. profil brody, owal twarzy, kształt szczęki, kości policzkowe, brwi;

- dodano elementy ciała dotyczące seksualności, tj. pośladki, piersi, narządy płciowe (autorzy oryginalnej skali uważali, że ich włączenie spowoduje wystąpienie tendencji do nieprawdziwego podwyższania oceny, która może wpłynąć na oceny innych części ciała);

- zmieniono kolejność itemów, co miało służyć temu, by pozycja ,aktywność seksualna” nie znajdowała się na początku listy, a ponadto stwarzać wrażenie „losowości”;

- dodano do oceny ciała aspekt znaczenia poszczególnych elementów ciała (oryginalnie nawiązano jedynie do aspektu zadowolenia, natomiast aspekt znaczenia wykorzystano przy procedurze tworzenia skali), który mierzony jest za pomocą arkusza KOC-2 testu;

- zmieniono instrukcję, prosząc badanych o wskazanie poziomu satysfakcji oraz znaczenia poszczególnych elementów ciała; 
- $\quad$ w oparciu o procedurę opisaną przez Franzoi oraz na podstawie wyników badania autorki wyodrębniono dwie podskale - KOC_Obiekt i KOC_Proces [29, 34];

- zmieniono nazwę skali.

Kwestionariusz Obrazu Ciała zawiera listę 54 części i funkcji ciała, które zorganizowane są w odwrotnym porządku alfabetycznym (od Z do A) i składa się z dwóch arkuszy testowych.

Wypełniając KOC-1 osoba badana wskazuje na stopień zadowolenia z poszczególnych elementów swojego ciała na skali od 1 do 5, gdzie 1 - bardzo niezadowolona/-y, 2 niezadowolona/-y, 3 - trudno powiedzieć, 4 - zadowolona/-y, 5 - bardzo zadowolona/-y, natomiast wypełniając arkusz KOC-2 osoba badana ujawnia, w jakim stopniu poszczególne elementy jej ciała są dla niej ważne (1 - w ogóle nieważne, 2 - raczej nieważne, 3 - trudno powiedzieć, 4 raczej ważne, 5 - bardzo ważne).

Składowymi KOC są trzy podskale:

1. KOC obliczany jest jako średnia arytmetyczna ocen wszystkich 54 elementów obrazu ciała.

2. KOC_Proces to średnia arytmetyczna z 12 elementów cielesności, które oceniane są w kontekście funkcjonowania, a nie wyglądu; są to: zdrowie, wydalanie, trawienie, sprawność fizyczna, sen, poziom energii, płeć, oddychanie, narządy płciowe, głos, apetyt i aktywność seksualna.

3. KOC_Obiekt to średnia arytmetyczna z pozostałych 42 elementów obrazu ciała, które oceniane są w kontekście wyglądu, a nie funkcjonowania; są to: zęby, wzrost, włosy, wiek, waga, uszy, usta, tył głowy, twarz, tułów, talia, szyja, szerokość ramion, struktura skóry, stopy, rozmieszczenie owłosienia na ciele, ramiona, profil twarzy, profil brody, pośladki, postawa ciała, plecy, piersi, palce dłoni, owal twarzy, oczy, nos, nogi, nadgarstki, kształt szczęki, kształt głowy, kości policzkowe, kostki, kolana, klatka piersiowa, dłonie, czoło, cera, budowa ciała, brwi, broda i biodra.

W odniesieniu do KOC możliwe jest uzyskanie sześciu wyników sumarycznych: KOC-1 stanowi miarę ogólnego zadowolenia z ciała, KOC-1_Proces wskazuje na poziom zadowolenia z funkcjonowania ciała, zaś KOC-1_Obiekt informuje o poziomie satysfakcji z wyglądu ciała. Analogicznie, KOC-2 jest miarą ogólnego znaczenia nadawanego ciału, KOC-2_Proces ujawnia ważność funkcjonalnego aspektu ciała dla osoby badanej, a KOC-2_Obiekt wskazuje na poziom znaczenia przypisywanego wyglądowi ciała.

Kwestionariusz Oceny Ciała charakteryzuje się wysoką rzetelnością - dla wszystkich skal sumarycznych współczynnik alfa Cronbacha przekracza wartość 0,8 .

Pacjenci wypełnili również kartę informacyjną dotyczącą wybranych danych osobowych i demograficznych, jak: waga, wzrost, wiek, wykształcenie, aktywność zawodowa, stan cywilny.

\section{Statystyczna analiza danych}

Celem analiz było ustalenie czy obraz siebie oraz wybrane zmienne socjodemograficzne i medyczne wpływają na sposób postrzegania własnego ciała u osób z wybranymi schorzeniami skóry.

Analizę składowych głównych przeprowadzono w celu zredukowania liczby zmiennych opisujących obraz siebie do kilku czynników. W pierwszym etapie badania określono liczbę czynników na podstawie dwóch kryteriów: wykresu osypiska Cattela oraz Kaisera. W wyniku przeprowadzonej analizy sformułowano pięć nowych zmiennych składowych, które następnie stanowiły zmienne potencjalne podczas analizy regresji.

Analizę regresji wielorakiej przeprowadzono w celu opisania związku między wybranymi zmiennymi objaśniającymi (oprócz uzyskanych składowych głównych jako potencjalne zmienne objaśniające przyjęto: wiek pacjentów, płeć badanych, wykształcenie, aktywność zawodową, fakt życia w związku małżeńskim lub partnerskim, BMI oraz czas choroby) a zmiennymi endogenicznymi (KOC-1, KOC-1_Proces, KOC-1_Obiekt, KOC-2, KOC-2_Proces, KOC-2_Obiekt). W badaniu wykorzystano model liniowy, a eliminację zmiennych przeprowadzano za pomocą metody krokowej wstecznej.

Analizę statystyczną przeprowadzono za pomocą odpowiednich modułów obliczeniowych pakietu Statistica 7.1 Pl.

\section{Wyniki}

Na podstawie wyników KOC (1 i 2) dokonano krótkiej charakterystyki obrazu ciała pacjentów z problemami dermatologicznymi.

Średnie wartości poszczególnych składowych oraz skal KOC-1 wskazujące na poziom zadowolenia z ciała u osób badanych, przedstawiono na rycinie 1 . W celu bardziej czytelnego zobrazowania podziału elementów obrazu ciała na aspekty funkcjonalne albo dotyczące wyglądu, kolorem ciemnoszarym wyróżniono składowe obrazu ciała należące do skali Proces. Wszystkie wyniki cząstkowe (KOC-1, KOC-1_Proces, KOC-1_Obiekt, KOC-2, KOC-2_Proces, KOC-2 Obiekt) oznaczono na czarno.

Jak można zauważyć, w badanej grupie osób cierpiących na schorzenia skóry niemal wszystkie wyniki poszczególnych składowych testu KOC-1 mieszczą się w przedziale 3-4 pkt, co wskazuje, iż poziom satysfakcji z poszczególnych elementów obrazu ciała oscyluje między kategorią neutralności i zadowolenia. Jedynie w odniesieniu do własnej płci poziom satysfakcji z ciała przekracza wartość 4 pkt, co stanowi maksimum profilu. Jednocześnie, w tej grupie chorych tylko w trzech przypadkach ocena elementów obrazu ciała mieści się poniżej poziomu neutralności (3 pkt). W odniesieniu do dwóch aspektów cielesności ocena ta jest bliska kategorii neutralności. Są to zdrowie i zęby. Elementem ciała ocenianym przez badanych jako niezadowalający (przyjmujący wartość 2,3 pkt) jest struktura skóry, który zarazem stanowi minimum profilu. Wyniki skal sumarycznych KOC-1, KOC-1_Obiekt, KOC-1_Proces przekraczają wartość 3,5 pkt, co wskazuje na przynajmniej umiarkowane 




Ryc. 1. Średnie wartości składowych KOC-1 oraz wskaźników cząstkowych w grupie dermatologicznej

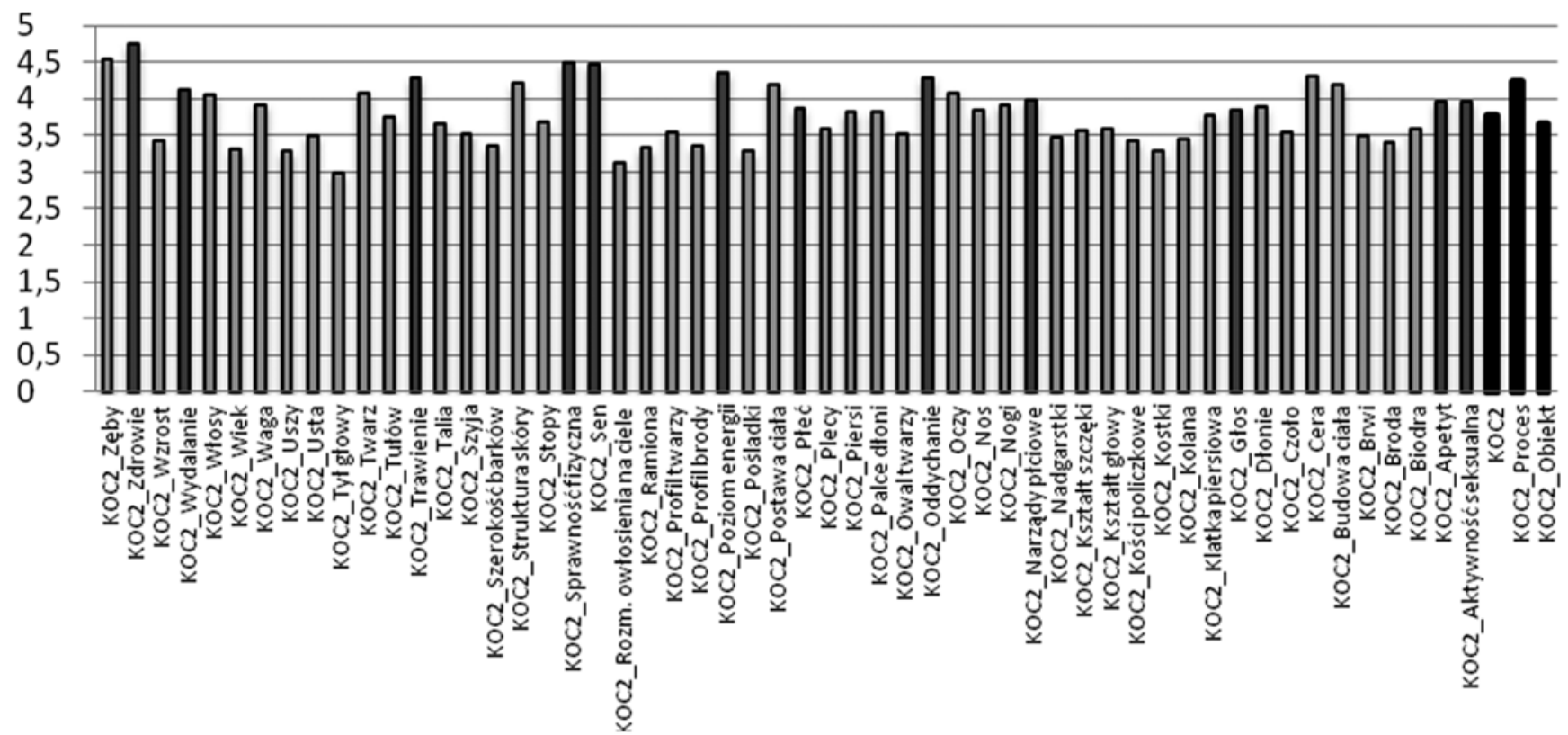

Ryc. 2. Średnie wartości składowych KOC-2 oraz wskaźników cząstkowych w grupie dermatologicznej

zadowolenie z własnego ciała, zarówno w aspekcie globalnym, wyglądu ciała, jak i jego funkcjonowania.

Analogicznie, średnie wartości dla poszczególnych składowych oraz skal KOC-2 (informujące o poziomie znaczenia przypisywanego ciału w badanej grupie) przedstawiono na rycinie 2.

Oceny dotyczące znaczenia przypisywanego różnym elementom obrazu ciała oscylują pomiędzy wartością 3 i 4,5 pkt. Największe znaczenie przypisywane jest takim elementom obrazu ciała, jak: zdrowie (maksimum profilu), sprawność fizyczna, sen, oddychanie, poziom energii i trawienie, czyli związanym z funkcjonowaniem ciała. Średnia wartość wskaźnika sumarycznego KOC-2_Proces jest wyższa od pozostałych wskaźników sumarycznych, co pozwala stwierdzić, iż aspekt funkcjonowania ciała jest relatywnie ważny dla badanych. Zwraca uwagę fakt, że w grupie chorych dermatologicznie duże znaczenie przypisywane jest także elementom „struktura skóry” oraz „,cera”, które należą do składników obrazu ciała ocenianych z punktu widzenia wyglądu, a ponadto stanowią te elementy obrazu ciała, których wygląd jest upośledzony przez chorobę.

Jak wspomniano, oceny obrazu siebie dokonano w oparciu o wyniki Kwestionariusza Stylu Spostrzegania „Koło” Bena Shalita oraz Testu Przymiotników ACL-37. Ze względu na znaczą liczebność wskaźników obrazu siebie, przed oszacowaniem wpływu tych i innych zmiennych na sposób postrzegania własnego ciała w grupie chorych dermatologicznie przeprowadzono analizę składowych głównych, 
której celem było zredukowanie liczby zmiennych opisujących obraz siebie do kilku czynników. Na podstawie przeprowadzonej analizy dwóch kryteriów (Kaisera oraz wykresu osypiska Cattela - ryc. 3) wyznaczono pięć czynników, które wyjaśniały łącznie $61,09 \%$ całkowitej wariancji.

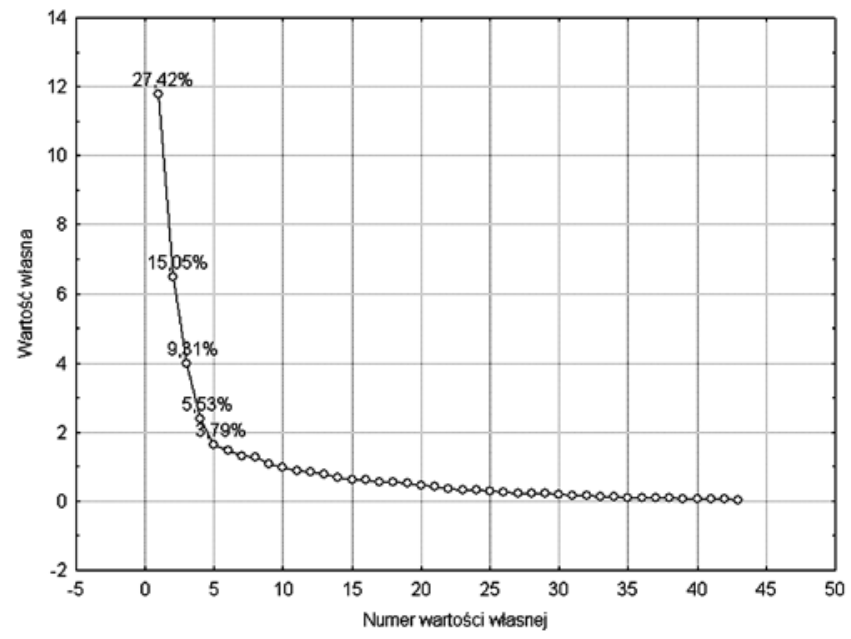

Ryc. 3. Wykres osypiska dla danych z grupy dermatologicznej

Sens psychologiczny każdego czynnika określono na podstawie zmiennych najsilniej z nim związanych. W tabeli 1 zamieszczono zestawienie wskaźników obrazu siebie najsilniej związane $\mathrm{z}$ wyodrębnionymi pięcioma czynnikami głównymi (wartości ładunków czynnikowych umieszczono obok zmiennych).

T a b e 1 a 1. Wskaźniki obrazu siebie najsilniej związane z czynnikami głównymi

\begin{tabular}{|c|c|c|}
\hline Czynnik 1 & $\begin{array}{l}\text { Fav }(-0,872) \\
\text { Ach }(-0,774) \\
\text { Dom }(-0,749) \\
\text { End }(-0,777) \\
\operatorname{Scf}(-0,772)\end{array}$ & $\begin{array}{l}\text { Iss }(-0,819) \\
\text { Mls }(-0,700) \\
\text { Np }(-0,831) \\
\text { A }(-0,810) \\
\text { Ac }(0,837)\end{array}$ \\
\hline Czynnik 2 & $\begin{array}{l}\text { Aut }(-0,813) \\
\text { Agg }(-0,841) \\
\text { Aba }(0,737) \\
\text { Def }(0,874) \\
\text { Cp }(-0,707)\end{array}$ & $\begin{array}{l}\text { nieco słabszy związek } \\
\text { ze zmiennymi: } \\
\text { Nur }(0,608) \\
\text { Scn }(0,658)\end{array}$ \\
\hline $\begin{array}{l}\text { Czynnik } 3 \\
\text { (słaby związek) }\end{array}$ & $\begin{array}{l}\text { Sfera emocjonalno- } \\
\text {-afektywna }(0,452) \\
\text { Ord }(-0,409) \\
\text { Nur }(0,491) \\
\text { Aff }(0,503) \\
\text { Het }(0,591) \\
\text { Exh }(0,473)\end{array}$ & $\begin{array}{l}\text { Cha }(0,557) \\
\text { Scn }(-0,503) \\
\text { Fem }(0,518) \\
\text { Fc }(0,475) \\
\text { A-1 }(0,447) \\
\text { A-3 }(0,460)\end{array}$ \\
\hline Czynnik 4 & A-2 $(-0,616)$ & $\begin{array}{l}\text { słaby związek } \\
\text { ze zmiennymi: } \\
\text { funkcjonowanie } \\
\text { poznawczo-intelektualne } \\
(-0,460) \\
\text { Crs }(-0,412) \\
\text { Fem }(-0,470) \\
\text { A-4 }(-0,405)\end{array}$ \\
\hline $\begin{array}{l}\text { Czynnik } 5 \\
\text { (słaby związek) }\end{array}$ & Inna $(0,444)$ & \\
\hline
\end{tabular}

Ze względu na fakt, iż w skład czynnika 3, 4 oraz 5 wchodziły wybrane kategorie Kwestionariusza Stylu Spostrzegania, tj. Sfera emocjonalno-afektywna, Funkcjonowanie poznawczo-intelektualne oraz Inna, przed podaniem charakterystyki każdego czynnika przeanalizowano odpowiednie kategorie testu „Koło” pod względem treści ujawnianych w badanej grupie.

\section{Czynnik 1. Słabość i zahamowanie}

W grupie chorych dermatologicznie Czynnik 1 składa się z dziewięciu skal ACL o ujemnych ładunkach czynnikowych: Liczba przymiotników pozytywnych (Fav), Potrzeba osiągnięć (Ach), Potrzeba dominacji (Dom), Potrzeba wytrwałości (End), Zaufanie do siebie (Scf), Skala idealnego obrazu siebie (Iss), Skala uzdolnień przywódczych (Mls), Wychowujący rodzic (Np), Dorosły (A) oraz jednej skali o dodatnim ładunku czynnikowym: Przystosowane dziecko (Ac).

Czynnik 1 opisują następujące charakterystyki: niepewność, lęk, niewiara w siebie, łatwość rozpraszania uwagi, zmienność, trudność w ustalaniu i osiąganiu celów, uprzejmość, skromność i wzgląd na innych, poszukiwanie zmiany i różnorodności, niestabilność, niska odporność na stres, unikanie odpowiedzialności, wrażliwość, a także: zahamowanie, trudność w mobilizowaniu własnych zasobów w działaniu, nieśmiałość, niechęć do podejmowania zadań wymagających wysiłku, zależność, unikanie bezpośredniej konfrontacji, skłonność do ucieczki w marzenia, niezdyscyplinowanie, unikanie rywalizacji i zaznaczania własnego ja.

\section{Czynnik 2. Pojednawczość}

W grupie osób cierpiących na choroby skóry Czynnik 2 składa się z trzech skal ACL o ujemnych ładunkach czynnikowych: Potrzeba agresywności (Agg), Potrzeba autonomii (Aut) i Krytyczny rodzic (Cp) oraz czterech skal o dodatnich ładunkach czynnikowych: Potrzeba poniżania się (Aba), Potrzeba podporządkowania się (Def), Potrzeba opiekowania się (Nur) i Samokontrola (Scn).

Psychologiczna charakterystyka Czynnika 2 to: preferowanie tego, co wypróbowane i pewne, unikanie ryzyka, poddawanie się kierownictwu, cierpliwość, wyrozumiałość, unikanie konfliktów, respektowanie życzeń i wymagań innych, poczucie mniejszej wartości, sumienność, skromność, podporządkowanie, a także: naturalność, taktowność, gotowość pomagania innym, nadmierna samokontrola, tolerancyjność, bezinteresowność.

\section{Czynnik 3. Emocjonalność (Serdeczność i impulsywność)}

W grupie osób chorych dermatologicznie Czynnik 3 jest zdefiniowany przez dwanaście zmiennych, $\mathrm{w}$ tym jedenaście skal ACL oraz kategorię Sfera emocjonalno-afektywna. Dziewięć skal ACL tworzących Czynnik 3 ma dodatnie ładunki czynnikowe. Są to: Potrzeba opiekowania się (Nur), Potrzeba afiliacji (Aff), Potrzeba kontaktów heteroseksualnych (Het), Potrzeba ujawniania się (Exh), Potrzeba zmiany (Cha), Skala kobiecości (Fem), Wolne dziecko (Fc), Wysoka 
oryginalność - niska inteligencja (A-1), Niska oryginalność niska inteligencja (A-3), natomiast dwie skale mają ujemne ładunki czynnikowe: Potrzeba porządku (Ord) i Samokontrola (Scn). Psychologiczne znaczenie tego układu skal wskazuje na: dobre samopoczucie w sytuacjach ekspozycji społecznej, towarzyskość, troskę i dbałość o innych, otwartość,

T a b e l a 2. Składowe kategorii Sfera emocjonalno-afektywna w grupie dermatologicznej

\begin{tabular}{|c|c|c|c|c|}
\hline Lp. & $\begin{array}{l}\text { Cechy kategorii } \\
\text { Sfera } \\
\text { emocjonalno- } \\
\text {-afektywna }\end{array}$ & Liczebność & $\begin{array}{l}\text { Liczebność } \\
\text { skumulo- } \\
\text { wana }\end{array}$ & $\begin{array}{l}\text { Skumulo- } \\
\text { wany pro- } \\
\text { cent liczeb- } \\
\text { ności }\end{array}$ \\
\hline 1 & nerwowy & 47 & 47 & 17,47 \\
\hline 2 & spokojny & 36 & 83 & 30,86 \\
\hline 3 & uczuciowy & 26 & 109 & 40,52 \\
\hline 4 & wrażliwy & 25 & 134 & 49,81 \\
\hline 5 & wesoły & 24 & 158 & 58,74 \\
\hline 6 & wybuchowy & 17 & 175 & 65,06 \\
\hline 7 & opanowany & 10 & 185 & 68,77 \\
\hline 8 & współczujący & 8 & 193 & 71,75 \\
\hline 9 & pogodny & 8 & 201 & 74,72 \\
\hline 10 & porywczy & 6 & 207 & 76,95 \\
\hline 11 & romantyk & 6 & 213 & 79,18 \\
\hline 12 & niecierpliwy & 5 & 218 & 81,04 \\
\hline 13 & lękliwy & 4 & 222 & 82,53 \\
\hline 14 & impulsywny & 4 & 226 & 84,01 \\
\hline 15 & nadpobudliwy & 4 & 230 & 85,50 \\
\hline 16 & płaczliwy & 3 & 233 & 86,62 \\
\hline 17 & pobudliwy & 3 & 236 & 87,73 \\
\hline 18 & smutny & 3 & 239 & 88,85 \\
\hline 19 & słaby psychicznie & 2 & 241 & 89,59 \\
\hline 20 & przewrażliwiony & 2 & 243 & 90,33 \\
\hline 21 & marudny & 2 & 245 & 91,08 \\
\hline 22 & stabilny & 2 & 247 & 91,82 \\
\hline 23 & przygnębiony & 2 & 249 & 92,57 \\
\hline 24 & kochliwy & 2 & 251 & 93,31 \\
\hline 25 & spontaniczny & 2 & 253 & 94,05 \\
\hline 26 & niespokojny & 1 & 254 & 94,42 \\
\hline 27 & zawiedziony & 1 & 255 & 94,80 \\
\hline 28 & zadowolony & 1 & 256 & 95,17 \\
\hline 29 & strachliwy & 1 & 257 & 95,54 \\
\hline 30 & zmienny & 1 & 258 & 95,91 \\
\hline 31 & radosny & 1 & 259 & 96,28 \\
\hline 32 & niezadowolony & 1 & 260 & 96,65 \\
\hline 33 & rozczarowany & 1 & 261 & 97,03 \\
\hline 34 & alkoholik & 1 & 262 & 97,40 \\
\hline 35 & sentymentalny & 1 & 263 & 97,77 \\
\hline 36 & znerwicowany & 1 & 264 & 98,14 \\
\hline 37 & agresywny & 1 & 265 & 98,51 \\
\hline 38 & niestabilny & 1 & 266 & 98,88 \\
\hline 39 & szczęśliwy & 1 & 267 & 99,26 \\
\hline 40 & zniechęcony & 1 & 268 & 99,63 \\
\hline 41 & $\begin{array}{l}\text { ma słabość } \\
\text { do używek }\end{array}$ & 1 & 269 & 100,00 \\
\hline
\end{tabular}

spontaniczność, serdeczność, pozytywną emocjonalność, ale jednocześnie powierzchowność, impulsywność, rozproszenie uwagi, trudność w odraczaniu gratyfikacji. Ponadto, składową tego czynnika jest kategoria Sfera emocjonalno-afektywna. Zestawienie cech tworzących kategorię Sfera emocjonalno-afektywna w grupie osób cierpiących na choroby skóry, a także liczebność cech, liczebność skumulowaną oraz skumulowany procent liczebności zawarto w tabeli 2.

W analizowanej grupie chorych ok. 50\% wszystkich wskazań w kategorii Sfera emocjonalno-afektywna dotyczyło zaledwie czterech cech: nerwowy, spokojny, uczuciowy, wrażliwy. Kolejne $25 \%$ wskazań odnosiło się do pięciu cech: wesoły, wybuchowy, opanowany, współczujący i pogodny. Dalsze 10\% wszystkich wskazań dotyczyło sześciu cech wymienianych przez osoby badane 4-6 razy: porywczy, romantyk, niecierpliwy, lękliwy, impulsywny i nadpobudliwy.

Cechy ujawniane przez osoby chore dermatologicznie w odniesieniu do Sfery emocjonalno-afektywnej wskazują na łatwość doświadczania pobudzenia emocjonalnego, wrażliwość na emocje innych (zarówno przyjemne, jak i przykre), tendencję do ujawniania silnej reakcji na bodźce emocjonalne i labilność emocjonalną, a więc wykazują podobieństwo do typu neurotycznego opisanego przez Eysencka [35]. Jednocześnie w opisie własnej osoby w tej grupie chorych często pojawiają się takie określenia, jak: spokojny, opanowany, wesoły i pogodny, które odnoszą się do zrównoważenia emocjonalnego. Oznacza to, że charakterystycznym aspektem obrazu siebie osób w tej grupie chorych jest pobudliwość emocjonalna, która niekoniecznie musi być ujawniona w zachowaniu. Pomimo doświadczania silnych emocji, osoby te mogą sprawiać na otoczeniu wrażenie raczej spokojnych i zrównoważonych.

\section{Czynnik 4. Konwencjonalność}

Czynnik 4 reprezentowany jest przez pięć zmiennych o ujemnych ładunkach czynnikowych, w tym cztery skale ACL: Gotowość na poddanie się poradnictwu psychologicznemu (Crs), Skala kobiecości (Fem), Wysoka oryginalność - wysoka inteligencja (A-2), Niska oryginalność wysoka inteligencja (A-4) oraz kategorię Funkcjonowanie poznawczo-intelektualne.

Charakterystyki opisowe tego czynnika to: pewność siebie, akceptacja siebie i swojej roli, pragmatyzm, zrównoważenie, ale także zdystansowanie, niepewność co do intencji innych, ambiwalencja w stosunku do innych, skłonność do krytyki i trwania przy swoim zdaniu. Istotą tego układu skal jest brak oryginalności i samodzielności w myśleniu oraz spostrzeganiu, a także brak dyscypliny wewnętrznej.

Zestawienie cech składających się na kategorię Funkcjonowanie poznawczo-intelektualne w grupie chorych dermatologicznie wraz z informacją o ich liczebności, liczebności skumulowanej oraz skumulowanym procencie liczebności zawarto w tabeli 3 .

W grupie osób cierpiących na choroby skóry kategoria Funkcjonowanie poznawczo-intelektualne charakteryzowana 
T a b e l a 3. Skladowe kategorii Funkcjonowanie poznawczo-intelektualne w grupie dermatologicznej

\begin{tabular}{|c|c|c|c|c|}
\hline Lp. & $\begin{array}{l}\text { Składowe katego- } \\
\text { rii Funkcjonowa- } \\
\text { nie poznawczo- } \\
\text {-intelektualne }\end{array}$ & Liczebność & $\begin{array}{c}\text { Liczebność } \\
\text { skumulo- } \\
\text { wana }\end{array}$ & $\begin{array}{l}\text { Skumulo- } \\
\text { wany pro- } \\
\text { cent liczeb- } \\
\text { ności }\end{array}$ \\
\hline 1 & $\begin{array}{l}\text { zamknięty } \\
\text { w sobie }\end{array}$ & 6 & 6 & 15,79 \\
\hline 2 & inteligentny & 5 & 11 & 28,95 \\
\hline 3 & spostrzegawczy & 4 & 15 & 39,47 \\
\hline 4 & zorganizowany & 4 & 19 & 50,00 \\
\hline 5 & twórczy & 3 & 22 & 57,89 \\
\hline 6 & zdolny & 2 & 24 & 63,16 \\
\hline 7 & rozważny & 2 & 26 & 68,42 \\
\hline 8 & realista & 2 & 28 & 73,68 \\
\hline 9 & wierzący & 1 & 29 & 76,32 \\
\hline 10 & dosłowny & 1 & 30 & 78,95 \\
\hline 11 & roztargniony & 1 & 31 & 81,58 \\
\hline 12 & skomplikowany & 1 & 32 & 84,21 \\
\hline 13 & z wyobraźnią & 1 & 33 & 86,84 \\
\hline 14 & przesądny & 1 & 34 & 89,47 \\
\hline 15 & religijny & 1 & 35 & 92,11 \\
\hline 16 & konkretny & 1 & 36 & 94,74 \\
\hline 17 & przewidujący & 1 & 37 & 97,37 \\
\hline 18 & nieskomplikowany & 1 & 38 & 100,00 \\
\hline
\end{tabular}

była głównie przez następujące określenia: zamknięty $\mathrm{w}$ sobie, inteligentny, spostrzegawczy, zorganizowany, twórczy, zdolny, rozważny, realista - prawie $75 \%$ wszystkich wskazań dotyczyło tych cech. Istotą tego wymiaru jest sprawność, oryginalność i samodzielność w myśleniu.

Pozostałe 25\% wszystkich wskazań stanowiło dziesięć cech podanych jednokrotnie, które odnoszą się do różnorodnych wymiarów postrzegania rzeczywistości: m.in. wiary w siłę wyższą (wierzący, religijny), złożoności obrazu własnej osoby (skomplikowany, nieskomplikowany), sposobu myślenia (dosłowny, konkretny) oraz cechy, którą Antonovsky określa mianem dalekowzroczności (np. z wyobraźnią, przewidujący) i uważa za bardzo ważną dla zdolności radzenia sobie w trudnej sytuacji [36].

\section{Czynnik 5. Zadaniowość}

$\mathrm{W}$ grupie chorych dermatologicznie Czynnik 5 reprezentowany był tylko przez jedną zmienną, tj. kategorię Inna testu „Koło”. W tabeli 4 zamieszczono zestawienie poszczególnych cech należących do kategorii Inna, ujawnianych przez osoby chore dermatologicznie jako charakterystyczne dla własnej osoby, a także ich liczebność, liczebność skumulowaną oraz skumulowany procent liczebności.

Analiza treści cech będących składowymi kategorii Inna wskazuje, iż istotą tego wymiaru jest skuteczność w realizowaniu zadań charakterystyczna dla funkcjonowania zawodowego - ponad 50\% wszystkich wskazań dotyczyła zaledwie sześciu cech: pracowity, punktualny, uporządkowany, konsekwentny, sumienny i zaradny, a kolejne $25 \%$ wskazań odnosiło się do następujących dziesięciu
T a b e l a 4. Skladowe kategorii Inna w grupie dermatologicznej

\begin{tabular}{|c|c|c|c|c|}
\hline Lp. & $\begin{array}{l}\text { Składowe } \\
\text { kategorii } \\
\text { Inna }\end{array}$ & Liczebność & $\begin{array}{l}\text { Liczebność } \\
\text { skumulo- } \\
\text { wana }\end{array}$ & $\begin{array}{c}\text { Skumulo- } \\
\text { wany pro- } \\
\text { cent liczeb- } \\
\text { ności }\end{array}$ \\
\hline 1 & pracowity & 47 & 47 & 19,83 \\
\hline 2 & punktualny & 21 & 68 & 28,69 \\
\hline 3 & uporządkowany & 15 & 83 & 35,02 \\
\hline 4 & konsekwentny & 14 & 97 & 40,93 \\
\hline 5 & sumienny & 13 & 110 & 46,41 \\
\hline 6 & zaradny & 10 & 120 & 50,63 \\
\hline 7 & obowiązkowy & 7 & 127 & 53,59 \\
\hline 8 & powolny & 7 & 134 & 56,54 \\
\hline 9 & leniwy & 7 & 141 & 59,49 \\
\hline 10 & zrównoważony & 6 & 147 & 62,03 \\
\hline 11 & zdyscyplinowany & 5 & 152 & 64,14 \\
\hline 12 & rozrywkowy & 5 & 157 & 66,24 \\
\hline 13 & aktywny & 5 & 162 & 68,35 \\
\hline 14 & systematyczny & 5 & 167 & 70,46 \\
\hline 15 & zawzięty & 5 & 172 & 72,57 \\
\hline 16 & pomysłowy & 4 & 176 & 74,26 \\
\hline 17 & optymista & 4 & 180 & 75,95 \\
\hline 18 & pesymista & 4 & 184 & 77,64 \\
\hline 19 & czuły & 4 & 188 & 79,32 \\
\hline 20 & oszczędny & 3 & 191 & 80,59 \\
\hline 21 & zazdrosny & 3 & 194 & 81,86 \\
\hline 22 & gospodarny & 3 & 197 & 83,12 \\
\hline 23 & niezdecydowany & 3 & 200 & 84,39 \\
\hline 24 & rzetelny & 3 & 203 & 85,65 \\
\hline 25 & wolny & 2 & 205 & 86,50 \\
\hline 26 & wytrwały & 2 & 207 & 87,34 \\
\hline 27 & energiczny & 2 & 209 & 88,19 \\
\hline 28 & $\begin{array}{l}\text { z poczuciem } \\
\text { humoru }\end{array}$ & 2 & 211 & 89,03 \\
\hline 29 & solidny & 2 & 213 & 89,87 \\
\hline 30 & profesjonalny & 2 & 215 & 90,72 \\
\hline 31 & niezłośliwy & 1 & 216 & 91,14 \\
\hline 32 & niekontaktowy & 1 & 217 & 91,56 \\
\hline 33 & oddany pracy & 1 & 218 & 91,98 \\
\hline 34 & humorzasty & 1 & 219 & 92,41 \\
\hline 35 & cichy & 1 & 220 & 92,83 \\
\hline 36 & praktyczny & 1 & 221 & 93,25 \\
\hline 37 & bez nałogów & 1 & 222 & 93,67 \\
\hline 38 & rozsądny & 1 & 223 & 94,09 \\
\hline 39 & kompetentny & 1 & 224 & 94,51 \\
\hline 40 & chłodny & 1 & 225 & 94,94 \\
\hline 41 & zamartwiający się & 1 & 226 & 95,36 \\
\hline 42 & niesystematyczny & 1 & 227 & 95,78 \\
\hline 43 & ciepły & 1 & 228 & 96,20 \\
\hline 44 & przedsiębiorczy & 1 & 229 & 96,62 \\
\hline 45 & spóźnialski & 1 & 230 & 97,05 \\
\hline 46 & zabezpieczony & 1 & 231 & 97,47 \\
\hline 47 & akceptujący & 1 & 232 & 97,89 \\
\hline 48 & muzykalny & 1 & 233 & 98,31 \\
\hline 49 & pilny & 1 & 234 & 98,73 \\
\hline 50 & dowcipny & 1 & 235 & 99,16 \\
\hline 51 & wyizolowany & 1 & 236 & 99,58 \\
\hline 52 & bezradny & 1 & 237 & 100,00 \\
\hline
\end{tabular}


T a b e 1 a 5 . Wyniki analizy regresji dla KOC-1 w grupie dermatologicznej

Podsumowanie regresji zmiennej zależnej: KOC-1

$\mathrm{R}=0,99105768 ; \mathrm{R}^{2}=0,98219533 ;$ Skoryg. $\mathrm{R}^{2}=0,98185512$

\begin{tabular}{lcccrrrr}
\hline & BETA & SD & B & SD & $t(157)$ & $p$ \\
\hline Aktywność zawodowa & $-0,078410$ & 0,022942 & $-0,215667$ & 0,063101 & $-3,41781$ & 0,000804 \\
\hline Emocjonalność & 0,416369 & 0,065698 & 0,021389 & 0,003375 & 6,33763 & 0,000000 \\
\hline Konwencjonalność & $-0,646903$ & 0,065003 & $-0,018994$ & 0,001909 & $-9,95192$ & 0,000000 \\
\hline
\end{tabular}

BETA - standaryzowany współczynnik regresji; B - współczynnik regresji

T a b e 1 a 6. Wyniki analizy regresji dla KOC-1_Proces w grupie dermatologicznej

\begin{tabular}{lcccccc}
\hline \multicolumn{7}{c}{ Podsumowanie regresji zmiennej zależnej: KOC-1_Proces } \\
$\mathrm{R}=0,99094014 ; \mathrm{R}^{2}=0,98196237 ;$ Skoryg. $\mathrm{R}^{2}=0,98161770$ \\
\hline BETA & $\mathrm{SD}$ & $\mathrm{B}$ & $\mathrm{SD}$ & $\mathrm{t}(157)$ & $\mathrm{p}$ \\
\hline Aktywność zawodowa & $-0,088551$ & 0,023091 & $-0,252196$ & 0,065765 & $-3,8348$ & 0,000182 \\
\hline Emocjonalność & 0,373335 & 0,066126 & 0,019858 & 0,003517 & 5,6458 & 0,000000 \\
\hline Konwencjonalność & $-0,698448$ & 0,065427 & $-0,021234$ & 0,001989 & $-10,6753$ & 0,000000 \\
\hline
\end{tabular}

BETA - standaryzowany współczynnik regresji; B - współczynnik regresji

T a b e 1 a 7. Wyniki analizy regresji dla KOC-1_Obiekt w grupie dermatologicznej

\begin{tabular}{|c|c|c|c|c|c|c|}
\hline \multicolumn{7}{|c|}{$\begin{array}{l}\text { Podsumowanie regresji zmiennej zależnej: KOC-1_Obiekt } \\
\mathrm{R}=0,98888086 ; \mathrm{R}^{2}=0,97788535 \text {; Skoryg. } \mathrm{R}^{2}=0,97760542\end{array}$} \\
\hline & BETA & SD & $\mathrm{B}$ & $\mathrm{SD}$ & $\mathrm{t}(158)$ & $\mathrm{p}$ \\
\hline Emocjonalność & 0,386262 & 0,071671 & 0,019694 & 0,003654 & 5,38940 & 0,000000 \\
\hline Konwencjonalność & $-0,605860$ & 0,071671 & $-0,017656$ & 0,002089 & $-8,45340$ & 0,000000 \\
\hline
\end{tabular}

BETA - standaryzowany współczynnik regresji; B - współczynnik regresji

T a b e 1 a 8 . Wyniki analizy regresji dla KOC-2 w grupie dermatologicznej

Podsumowanie regresji zmiennej zależnej: KOC-2

$\mathrm{R}=0,98560023 ; \mathrm{R}^{2}=0,97140781 ;$ Skoryg. $\mathrm{R}^{2}=0,97104588$

\begin{tabular}{lcccccc}
\hline & BETA & SD & B & SD & t(158) & p \\
\hline Słabość i zahamowanie & 0,78365 & 0,139124 & 0,019684 & 0,003494 & 5,6327 & 0,000000 \\
\hline Konwencjonalność & $-0,605860$ & 0,139124 & $-0,054594$ & 0,004309 & $-12,6697$ & 0,000000 \\
\hline
\end{tabular}

BETA - standaryzowany współczynnik regresji; B - współczynnik regresji

T a b e 1 a 9. Wyniki analizy regresji dla KOC-2_Proces w grupie dermatologicznej

\begin{tabular}{lcccccrr}
\hline \multicolumn{7}{c}{ Podsumowanie regresji zmiennej zależnej: KOC-2_Proces } \\
$\mathrm{R}=0,99061233 ; \mathrm{R}^{2}=0,98131279 ;$ Skoryg. $\mathrm{R}^{2}=0,98107625$ \\
\hline Słabość i zahamowanie & BETA & $\mathrm{SD}$ & $\mathrm{B}$ & $\mathrm{SD}$ & $\mathrm{t}(158)$ & $\mathrm{p}$ \\
\hline Konwencjonalność & $-1,68884$ & 0,112473 & $-0,058353$ & 0,003886 & $-15,0155$ & 0,000000 \\
\hline
\end{tabular}

BETA - standaryzowany współczynnik regresji; B - współczynnik regresji

T a b e 1 a 10. Wyniki analizy regresji dla KOC-2_Obiekt w grupie dermatologicznej

\begin{tabular}{lccccccr}
\hline \multicolumn{7}{c}{ Podsumowanie regresji zmiennej zależnej: KOC-2_Obiekt } \\
$\mathrm{R}=0,98209999 ; \mathrm{R}^{2}=0,96452038 ;$ Skoryg. $\mathrm{R}^{2}=0,96407127$ \\
\hline Słabość i zahamowanie & BETA & $\mathrm{SD}$ & $\mathrm{B}$ & $\mathrm{SD}$ & $\mathrm{t}(158)$ & $\mathrm{p}$ \\
\hline Konwencjonalność & $-1,780539$ & 0,154977 & 0,019672 & 0,003785 & 5,1968 & 0,000001 \\
\hline
\end{tabular}

BETA - standaryzowany współczynnik regresji; B - współczynnik regresji

cech: obowiązkowy, powolny, leniwy, zrównoważony, kompetentny, niesystematyczny, przedsiębiorczy, spóźnialzdyscyplinowany, rozrywkowy, aktywny, systematyczny, ski, zabezpieczony, pilny, bezradny), jak i gospodarnością zawzięty, pomysłowy. Pozostałe $25 \%$ wskazań dotyczyło (oszczędny, gospodarny, praktyczny, rozsądny), relacjami zarówno cech wiążących się z zadaniowością (rzetelny, z innymi ludźmi (czuły, zazdrosny, niekontaktowy, chłodny, powolny, wytrwały, solidny, profesjonalny, oddany pracy, ciepły, akceptujący, wyizolowany), sposobem odnoszenia 
się do rzeczywistości (np. optymista, pesymista, z poczuciem humoru, niezłośliwy), a także szczególnymi uzdolnieniami (muzykalny).

W dalszej kolejności przeprowadzono analizę regresji w celu oszacowania wpływu wybranych właściwości osobowości oraz zmiennych socjodemograficznych, medycznych i cech fizycznych na sposób postrzegania własnego ciała w badanej grupie osób chorych dermatologicznie.

Jako potencjalne zmienne objaśniające przyjęto pięć czynników opisujących obraz siebie badanych (Słabość i zahamowanie, Pojednawczość, Emocjonalność, Konwencjonalność i Zadaniowość), wiek pacjentów, płeć badanych, wykształcenie, aktywność zawodową, fakt życia w związku małżeńskim lub partnerskim, BMI oraz czas choroby (w miesiącach).

Zmiennymi zależnymi w analizie regresji były wskaźniki sumaryczne KOC opisujące poziom zadowolenia z ciała w różnych jego aspektach - zadowolenia $\mathrm{z}$ własnego ciała (KOC-1), satysfakcję z funkcjonowania ciała (KOC-1_Proces) oraz zadowolenie z wyglądu ciała (KOC-1_Obiekt), a także wskaźniki sumaryczne wskazujące na zaabsorbowanie wspomnianymi aspektami własnej cielesności ogólnego znaczenia ciała (KOC-2), jego funkcjonowania (KOC-2_Proces) i wyglądu ciała (KOC-2_Obiekt). Wyniki analizy regresji (bez wyrazu wolnego) dla poszczególnych zmiennych zależnych opisujących obraz ciała dla grupy dermatologicznej przestawiono w tabeli 5 .

W grupie osób z chorobami skóry poziom ogólnej satysfakcji z ciała (KOC-1) zależny był od dwóch wymiarów osobowości - Konwencjonalności i Emocjonalności oraz od aktywności zawodowej, przy czym osoby nieaktywne zawodowo, a zatem renciści lub emeryci wykazywali znacznie mniejszą satysfakcję z ciała niż osoby pracujące lub bezrobotne. Wymiar Konwencjonalności najsilniej kształtował poziom ogólnego zadowolenia z ciała, przy czym większe natężenie tego wymiaru w osobowości badanych powodowało zmniejszenie ogólnej satysfakcji z własnego ciała. Z kolei większej Emocjonalności towarzyszyło większe zadowolenie $\mathrm{z}$ ciała.

Podobne wyniki uzyskano dla zmiennej KOC-1_Proces opisującej poziom satysfakcji z funkcjonowania ciała (tab. 6). Największy wpływ na poziom satysfakcji z funkcjonowania ciała miał wymiar Konwencjonalności, a następnie wymiar Emocjonalności. W małym stopniu zadowolenie $\mathrm{z}$ funkcjonalnego aspektu ciała wynikało $\mathrm{z}$ aktywności zawodowej. Kierunek wpływu każdego z wymienionych czynników na poziom satysfakcji z funkcjonowania ciała był identyczny jak w przypadku ogólnej satysfakcji z ciała, tj. wymiar Emocjonalności powodował zwiększenie ogólnej satysfakcji z własnego ciała, natomiast wymiar Konwencjonalności - zmniejszenie jej poziomu.

Wyniki analizy regresji uzyskane dla zmiennej KOC-1_ Obiekt opisującej poziom zadowolenia $\mathrm{z}$ wyglądu ciała zawarto w tabeli 7. Ze wszystkich zmiennych potencjalnych jedynie czynniki Emocjonalności oraz Konwencjonalności okazały się statystycznie istotne, przy czym wymiary te wpływały na poziom satysfakcji z wyglądu ciała w odmienny sposób. Wyższy poziom wymiaru Emocjonalności zwiększał poziom satysfakcji z wyglądu ciała, natomiast wyższy poziom wymiaru Konwencjonalności obniżał ją.

Wyniki analizy regresji otrzymane dla zmiennej KOC-2 opisującej poziom subiektywnego znaczenia przypisywanego ciału w grupie osób cierpiących z powodu schorzeń skórnych zawarto w tabeli 8 . W badanej grupie chorych poziom znaczenia przypisywanego ciału kształtowany był jedynie przez dwa wymiary osobowości - Słabość i zahamowanie oraz Konwencjonalność, przy czym ich wpływ był przeciwstawny - wyższy poziom Słabości i zahamowanie w osobowości badanych zwiększał poziom subiektywnego znaczenia ciała, natomiast wyższy poziom Konwencjonalności obniżał go.

Wyniki analizy regresji uzyskane dla zmiennej KOC2 Proces opisującej poziom subiektywnego znaczenia przypisywanego funkcjonowaniu ciała zawarto $w$ tabeli 9. Jak się okazało, również poziom subiektywnego znaczenia przypisywanego funkcjonowaniu ciała kształtowany był jedynie przez wymiar Konwencjonalności oraz Słabości i zahamowania (wyższy poziom wymiaru Słabość i zahamowanie zwiększał poziom subiektywnego znaczenia przypisywanego funkcjonowaniu ciała, a wyższy poziom Konwencjonalności obniżał go).

Wyniki analizy regresji otrzymane dla zmiennej KOC-2 Obiekt wskazujące na poziom zaabsorbowania wyglądem własnego ciała w grupie osób chorych dermatologicznie przedstawiono w tabeli 10. Podobnie jak w przypadku omówionych zmiennych, poziom subiektywnego znaczenia przypisywanego wyglądowi ciała kształtowany był jedynie przez wymiary Konwencjonalności oraz Słabości i zahamowania, a ich wpływ był przeciwstawny - wyższy poziom Słabości i zahamowania w osobowości badanych zwiększał poziom subiektywnego znaczenia nadawanego wyglądowi ciała, natomiast wyższy poziom Konwencjonalności obniżał go.

\section{Dyskusja}

W grupie osób cierpiących na schorzenia skóry poziom satysfakcji z większości elementów obrazu ciała oscylował pomiędzy kategorią neutralności i zadowolenia. Badani byli więcej niż zadowoleni z własnej płci, a szczególnie niezadowoleni ze struktury skóry. Ogólnie, osoby badane ujawniły więcej niż umiarkowane zadowolenie $\mathrm{z}$ własnego ciała, zarówno w zakresie jego ogólnej oceny, wyglądu, jak i funkcjonowania. Największe znaczenie przypisywane było następującym aspektom cielesności: zdrowie (najwyższa wartość w profilu), sprawność fizyczna, sen, oddychanie, poziom energii i trawienie, czyli odnoszącym się do funkcjonowania ciała. Spośród składników obrazu ciała ocenianych z punktu widzenia wyglądu relatywnie duże znaczenie przypisywane było dwóm elementom: struktura skóry oraz 
cera, co wydaje się być zrozumiałe, jako że w tej grupie chorych niekorzystne zmiany chorobowe dotyczyły właśnie wymienionych obszarów ciała.

Ocena obrazu siebie w grupie osób z chorobami skóry umożliwiła wyłonienie pięciu głównych czynników opisujących właściwości osobowości badanych. Były to: I. Słabość i zahamowanie. II. Pojednawczość. III. Emocjonalność. IV. Konwencjonalność. V. Zadaniowość. Istotą wymiaru Słabości i zahamowania była niewiara we własną skuteczność połączona $\mathrm{z}$ trudnością w mobilizowaniu siebie do długotrwałego wysiłku, co wynikało ze znacznej wrażliwości emocjonalnej, niechęci do konfrontacji i podejmowania się trudnych zadań oraz tendencji do fantazjowania. Kluczowa dla wymiaru Pojednawczości była dbałość o pozytywny klimat emocjonalny w relacjach z innymi ludźmi, nawet kosztem ekspresji własnych potrzeb i dążeń. Wyższemu natężeniu Emocjonalności towarzyszyła: znaczna pobudliwość emocjonalna, czerpanie satysfakcji z kontaktów z innymi ludźmi oraz mała kontrola własnych impulsów i działań, a także upodobanie do różnorodności. Z kolei charakterystyczny dla osób o wyższym nasileniu Konwencjonalności był przede wszystkim brak oryginalności i sprawności w myśleniu oraz ambiwalentny stosunek do innych ludzi wynikający z niepewności co do ich intencji, ale również akceptacja własnej roli społecznej, zrównoważenie oraz pragmatyczne postrzeganie rzeczywistości. Wreszcie, istotą czynnika określonego jako Zadaniowość była skuteczność w realizowaniu zadań, typowa dla sfery zawodowej.

Następnie w analizie regresji sprawdzono, jakie czynniki kształtują ocenę własnej cielesności u osób chorych dermatologicznie, przy czym oprócz wymienionych wymiarów osobowości, uwzględniono także czynniki socjodemograficzne (wiek, płeć, wykształcenie, aktywność zawodową, fakt życia w związku małżeńskim/partnerskim), fizyczne (BMI) i medyczne (czas choroby).

Jak się okazało, sposób postrzegania własnego ciała w grupie osób ze schorzeniami skóry kształtowany był przez cztery zmienne potencjalne: Słabość i zahamowanie, Emocjonalność, Konwencjonalność oraz aktywność zawodową. Zwraca uwagę fakt, iż aż trzy spośród nich opisywały wymiary osobowości. Największy wpływ na obraz ciała w tej grupie badanych miał wymiar Konwencjonalności. Wymiar ten kształtował wszystkie analizowane wskaźniki obrazu ciała, przy czym kierunek tej zależności był ujemny - wyższy poziom Konwencjonalności związany był z niższym poziomem satysfakcji z ciała (KOC-1, KOC-1_Proces, KOC-1_Obiekt), jak również mniejszym znaczeniem przypisywanym ciału (KOC-2, KOC-2_Proces, KOC-2_Obiekt).

Uzyskane wyniki częściowo znajdują potwierdzenie w literaturze przedmiotu. Psychologiczne znaczenie czynnika Konwencjonalności wskazuje na skłonność do realizowania uprzednio zinternalizowanych norm społecznych, podążenia za ustalonymi sposobami funkcjonowania zarówno w sferze społecznej, jak i intelektualnej. Można zatem oczekiwać, że osoby, w których osobowości aspekt ten jest wyraźniejszy, również w ocenie własnego ciała będą kierować się oczekiwaniami społecznymi, a więc przejawiać nastawienie wobec cielesności charakterystyczne dla przedstawicieli danej kultury. W istocie przekonania dotyczące roli społecznej wymienia się jako czynnik wpływający na sposób postrzegania własnego ciała [37]. Według Casha, tradycyjne przekonania dotyczące relacji partnerskich skłaniają kobiety do identyfikowania się z kulturowymi standardami piękna i większego zaangażowania w ich realizowanie [37]. Niektórzy autorzy wskazują, że kobiety poddawane są silniejszej presji społecznej odnośnie spełniania kulturowych wymogów atrakcyjności niż mężczyźni [38]. W perspektywie socjokulturowej zwraca się jednak uwagę, że atrakcyjni mężczyźni doświadczają podobnych korzyści społecznych, jak atrakcyjne kobiety [17]. Z kolei w teorii ewolucyjnej podkreśla się, że cechy fizyczne będące oznaką choroby (np. zmiany skórne) postrzegane są jako nieatrakcyjne lub wręcz odstręczające bez względu na płeć danej osoby [39]. W tym kontekście zrozumiałe wydaje się, iż osoby bardziej konwencjonalne mogą ujawniać mniejsze zadowolenie z własnego ciała, zwłaszcza gdy ich wygląd jest niekorzystnie zmieniony przez chorobę, jednak zaskakuje fakt, że jednocześnie wydają się przykładać mniejszą wagę do swej cielesności.

Pozostałe wymiary obrazu siebie wpływały na odmienne aspekty obrazu ciała w tej grupie chorych. Czynnik Emocjonalności kształtował poziom satysfakcji z ciała zarówno w aspekcie ogólnym (KOC-1), jak i funkcjonowania (KOC-1_Proces) oraz wyglądu ciała (KOC-1_Obiekt), przy czym większe nasilenie tego wymiaru osobowości związane było z większym zadowoleniem z własnego ciała. W badanej grupie osób istotą wymiaru Emocjonalności była znaczna pobudliwość emocjonalna (dotycząca zarówno emocji negatywnych, jak i pozytywnych), impulsywność i upodobanie do zmian, ale także zdolność do opanowania emocji i serdeczność w kontaktach interpersonalnych. Jakkolwiek wśród pacjentów ze schorzeniami skóry zmiany chorobowe często stanowią źródło negatywnych emocji (takich jak lęk, gniew) [15], możliwe jest, iż otwartość w przejawianiu emocji u tych osób - szczególnie jeśli towarzyszy jej dbałość o jakość relacji - pozwala na większą akceptację własnej cielesności.

Czynnik Słabości i zahamowania związany był wyłącznie z poziomem znaczenia ciała (we wszystkich jego aspektach), przy czym kierunek tej zależności również był dodatni: osoby ujawniające w obrazie siebie wyższe nasilenie Słabości i zahamowania nadawały większe znaczenie swojej cielesności. Wyniki te są zgodne z intuicją. Ponieważ istotą wymiaru Słabość i zahamowanie jest brak poczucia sprawstwa, koncentracja na niedomaganiach ciała w sytuacji choroby może w tej grupie osób pełnić funkcję adaptacyjną (pozwala bowiem na uzyskanie pewnego rodzaju uzasadnienia lub też usprawiedliwienia dla własnej bezradności, braku samodzielności i zaradności, co w psychologii zdrowia określa się jako zysk wtórny z choroby) [40].

Najmniejszy wpływ na obraz ciała osób chorych dermatologicznie miała aktywność zawodowa. Jak można było 
oczekiwać, osoby nieaktywne zawodowo (renciści lub emeryci) wykazywały znacznie mniejszą satysfakcję z ciała niż osoby pracujące lub bezrobotne, zarówno $\mathrm{w}$ aspekcie ogólnym (KOC-1), jak i funkcjonowania ciała (KOC-1_Proces). Oprócz doświadczania reakcji społecznych z powodu widocznych zmian skórnych, część tych chorych mogła również doznawać pewnych dolegliwości somatycznych i ograniczeń funkcjonalnych. W konsekwencji brak pełnej sprawności ciała powstrzymywał te osoby przed podjęciem zobowiązań zawodowych.

\section{Wnioski}

1. Obraz ciała osób chorych dermatologicznie kształtowany był przede wszystkim przez wymiary osobowości.

2. Największy wpływ na obraz ciała w tej grupie badanych miał wymiar Konwencjonalności, który charakteryzuje brak oryginalności i samodzielności w myśleniu i spostrzeganiu, tendencja do podążania za ustalonymi wzorcami, pragmatyzm oraz ambiwalentny stosunek do innych. Wyższy poziom Konwencjonalności w osobowości badanych związany był z niższym poziomem satysfakcji z ciała, jak również mniejszym znaczeniem przypisywanym ciału. Z kolei osoby charakteryzujące się większą Emocjonalnością były bardziej zadowolone z ciała. Chorzy ujawniający w obrazie siebie wyższe nasilenie Słabości i zahamowania nadawali większe znaczenie swojej cielesności.

\section{Piśmiennictwo}

1. Krueger D.: Psychodynamic perspectives on body image. In: Body image. A handbook of theory, research, and clinical practice. Eds. T. Cash, T. Pruzinsky. The Guilford Press, New York 2002, 30-37.

2. McCabe M.P., Ricciardelli L.A.: Body image dissatisfaction among males across the lifespan. A review of past literature. J Psychosom Res. 2004, 56, 675-685.

3. Cash T.: Cognitive-behavioral perspectives on body image. In: Body image. A handbook of theory, research, and clinical practice. Eds. T. Cash, T. Pruzinsky. The Guilford Press, New York 2002, 38-46.

4. Tiggemann M.: Media influences on body image development. In: Body image. A handbook of theory, research, and clinical practice. Eds. T. Cash, T. Pruzinsky. The Guilford Press, New York 2002, 91-98.

5. Kearney-Cooke A.: Familiar influences on body image development. In: Body image. A handbook of theory, research, and clinical practice. Eds. T. Cash, T. Pruzinsky. The Guilford Press, New York 2002, 98-107.

6. Tantleff-Dunn S., Gokee J.: Interpersonal influences on body image development. In: Body image. A handbook of theory, research, and clinical practice. Eds. T. Cash, T. Pruzinsky. The Guilford Press, New York 2002, 108-116.

7. Kralik D., Koch T., Eastwood S.: The salience of the body: transition in sexual self-identity form women living with multiple sclerosis. J Adv Nurs. 2003, 42 (1), 11-20.

8. Rumsey N.: Body image and congenial conditions with visible differences. In: Body image. A handbook of theory, research, and clinical practice. Eds. T. Cash, T. Pruzinsky. The Guilford Press, New York 2002, 226-233.

9. Papadopoulos L., Walker C., Aitken D., Bor R.: The relationship between body location and psychological morbidity in individuals with acne vulgaris. Psychol Health Med. 2000, 5, 4, 431-438.
10. Papadopoulos L., Bor R., Legg C.: Coping with the disfiguring effect of vitiligo: a preliminary investigation into the effects of cognitive-behavioural therapy. Br J Med Psychol. 1999, 72, 385-396.

11. Wenninger K., Weiss C., Wahn U., Staab D.: Body image in cystic fibrosis - Development of a brief diagnostic scale. J Behav Med. 2003, 26, 81-94.

12. Papadopoulos L., Walker C.: Understanding skin problems. John Wiley and Sons, Chichester 2003.

13. Szepietowski J., Pacan P.: Dermatozy wymagające pomocy psychiatryczno-psychologicznej. Adv Clin Exp Med. 2001, 10 (3), Suppl. 1, 25-28.

14. Miniszewska J., Chodkiewicz J., Zalewska A.: Psychodermatologia nowe wyzwanie dla psychologii. Now Psychol. 2004, 3, 21-29.

15. Steuden S., Janowski K.: Zastosowanie kwestionariusza SKINDEX do pomiaru jakości życia u pacjentów z łuszczycą. Przegl Dermatol. 2001, 88 (1), 41-48.

16. Bogaczewicz J., Kuryłek A., Woźniacka A., Sysa-Jędrzejowska A., Zalewska-Janowska A.: Techniki relaksacyjne w psychodermatologii. Derm Klin. 2008, 10 (4), 223-225.

17. Jackson L.: Physical attractiveness: a sociocultural perspective. In: Body image. A handbook of theory, research, and clinical practice. Eds. T. Cash, T. Pruzinsky. The Guilford Press, New York 2002, 13-21.

18. Baudouin J.Y., Tiberhien G.: Symmetry, averageness, and feature size in the facial attractiveness of women. Acta Psychol. 2004, 117, $313-332$.

19. Slof R., Mazzeo S., Bulik C.: Characteristics of women with persistent thinness. Obes Res. 2003, 11 (8), 971-977.

20. Głębocka A., Wiśniewska A.: Psychologiczny portret kobiet otyłych. In: Wizerunek ciała. Portret Polek. Eds. A. Głębocka, J. Kulbat. Wyd. Uniw. Opolskiego, Opole 2005, 63-78.

21. Wooley O.W., Roll S.: The Color-A-Person Body Dissatisfaction Test: stability, internal consistency, validity and factor structure. J Pers Assess. 1991, 56 (3), 395-413.

22. Mandal E.: Ciało jako proces - ciało jako obiekt. Obraz ciała u studentów Akademii Wychowania Fizycznego i studentów kierunków uniwersyteckich. Czas Psychol. 2004, 10 (1), 35-47.

23. Bardziejewska M.: Okres dorastania. Jak rozpoznać potencjał nastolatków? In: Psychologiczne portrety człowieka. Ed. A. Brzezińska. PWN, Gdańsk 2005, 345-378.

24. Ferraro F.R., Muehlenkamp J.J., Paintner A., Wasson K., Hager T., Hoverson F.: Aging, body image and body shape. J Gen Psychol. 2008, 135 (4), 379-392.

25. Gilbert-Diamond D., Baylin A., Mora-Plazas M., Villamor E.: Correlates of obesity and body image in Colombian women. J Womens Health. 2009, 18 (8), 1145-1151.

26. Boyes A.D., Fletcher G.J., Latner J.D.: Male and female body image and dieting in the context of intimate relationships. J Fam Psychol. 2007, 21 (4), 764-768.

27. Swami V., Hadji-Michael M., Furnham A.: Personality and individual difference correlates of positive body image. Body Image. 2008, 5, 322-325.

28. Shaw H., Stice E., Springer D.: Perfectionism, body dissatisfaction, and self-esteem in predicting bulimic symptomatology: lack of replication. Int J Eat Disord. 2004, 36, 41-47.

29. Franzoi S.L.: The body-as-object versus the body-as-process: gender differences and gender considerations. Sex Roles. 1995, 33 (5/6), 417-437.

30. Czapiński J.: Koło Shalita - kwestionariusz stylu spostrzegania. In: Materiały do nauczania psychologii, seria III, t. 4. Ed. L. Wołoszynowa. PWN, Warszawa 1985

31. Zarek A.: Obraz siebie u osób po pierwszym zawale serca, pacjentów z wybranymi chorobami dermatologicznymi i osób zdrowych. Ann Acad Med Stetin. 2013, 59 (2), 29-38.

32. Oleś P., Juros A.: Struktura czynnikowa i skupieniowa Testu Przymiotnikowego ACL H.G. Gougha i A.B. Heilbruna. In: Z psychometrycznych problemów diagnostyki psychologicznej. Eds. J. Brzeziński, E. Hornowska. UAM, Poznań 1992, 171-201. 
33. Secord P., Jourard S.: The appraisal of body cathexis: body cathexis and the self. J Consult Psychol. 1953, 17 (5), 343-347.

34. Zarek A.: Obraz ciała w ujęciu procesu lub obiektu a satysfakcja z własnego ciała. Ann Acad Med Stetin. 2009, 55 (1), 100-106.

35. Oleś P.: Wprowadzenie do psychologii osobowości. Wyd. Nauk. Scholar, Warszawa 2008.

36. Sheridan C.L., Radmacher S.A.: Psychologia zdrowia. Instytut Psychologii Zdrowia, Warszawa 1998.
37. Cash T:: The Situational Inventory of Body-Image Dysphoria: psychometric evidence and development of a short form. Int J Eat Disord. 2002, 32, 362-366.

38. Fredrickson B.L., Roberts T.A.: Objectification theory. Toward understanding women's lived experiences and mental health risks. Psychol Women Quaterly. 1997, 21, 171-206.

39. Buss D.: Ewolucja pożądania. GWP, Gdańsk 2007.

40. Jarosz M.: Psychologia lekarska. PZWL, Warszawa 1988. 